\title{
Nordisk judaistik Scandinavian Jewish Studies
}

\author{
EDITORIAL
}

rets andra nummer av Nordisk judais-
tik innehåller fyra artiklar och en bok-
recension. I "Gestaltningen och etableringen av Förintelseminnet i Sverige" går Tanja Schult igenom de minnesmärken över Förintelsens offer som uppfördes i Sverige mellan åren 1949 och 1998 och diskuterar den förändring i minneskulturen som de illustrerar. De tidiga monumenten uppfördes huvudsakligen på judiska begravningsplatser och uppfattades framför allt som en judisk angelägenhet, men när Förintelsen med tiden blev en del också av det icke-judiska samhällets minne och ansträngningarna att hålla minnet av den vid liv också blev en angelägenhet för det svenska samhället i stort, kom monumenten att få en alltmer central och synlig placering.

I artikeln "Swedish interventions in the tragedy of the Jews of Slovakia" redogör författarna Denisa Neštáková och Eduard Nižňanský för tidigare icke uppmärksammade försök från svensk sida att rädda slovakiska judar undan deportation åren I942-I 944. Härvidlag uppmärksammar de särskilt de insatser som det svenska konsulatet i Bratislava gjorde tillsammans med ärkebiskop Erling Eidem och Bohumil Pissko, den slovakiske konsuln i Sverige.
Harry R. Svensson presenterar i sin artikel "Den östjudiska invandringen till Karlskrona” en detaljerad analys, baserad på extensiv arkivforskning, av hur den judiska befolkningsstrukturen i staden Karlskrona förändrades och utvecklades i och med den ökande inflyttningen av judar till Sverige från framförallt Polen från mitten av i 80otalet och framåt. Slutligen återpublicerar NJ den högaktuella artikeln "Different antisemitisms: on three distinct forms of antisemitism in contemporary Europe. With a special focus on Sweden" skriven av Lars Dencik och Karl Marosi (tidigare $\mathrm{i}$ år utgiven av the Kantor Center for the Study of Contemporary European Jewry vid Tel Avivs universitet). Sist i detta nummer recenserar Keith KahnHarris den samlingsvolym som blev resultatet av en konferens som hölls i Åbo i mars 20 I 5 , Jewish Studies in the Nordic Countries Today.

Nyetableringen av NJ som en open access e-journal har överträffat alla förväntningar och vi redaktörer vill rikta ett varmt tack till alla skribenter, granskare och övriga som bidragit till att blåsa liv i tidskriften och sprida information om den i internationella nätverk. Vi ser med tillförsikt fram emot att fortsätta utgivningen med två nummer under nästa år. 
a collection of articles originally presented at a conference held in Åbo, Finland, in March

This year's second issue of Scandinavian Jewish Studies includes four articles and a book review. Tanja Schult's article provides a survey of the Holocaust monuments established in Sweden between 1949 and 1998, and a discussion of how they illustrate the ways in which the Holocaust is remembered. The early monuments were built in Jewish cemeteries and were seen primarily as a Jewish concern, but over time, as the Holocaust entered the collective memory of the nonJewish population, newer ones were built in more public places where they are more easily seen and noticed by everyone.

In 'Swedish interventions in the tragedy of the Jews of Slovakia' Denisa Neštáková and Eduard Nižňanský describe the relatively unknown Swedish attempts to rescue Slovakian Jews in 1942-5, highlighting in particular the efforts made by the Swedish consulate in Bratislava together with Archbishop Erling Eidem and Bohumil Pisko, the Slovakian Consul in Sweden.

In his article, 'Den östjudiska invandringen till Karlskrona', Harry R. Svensson gives a detailed analysis, based on meticulous archive research, on how the Jewish population changed and developed in the city of Karlskrona in Sweden as a result of the increased immigration of Jews to Sweden especially from Poland, commencing in the mid-twentieth century. Scandinavian Jewish Studies also republishes the topical article 'Different antisemitisms: on three distinct forms of antisemitism in contemporary Europe. With a special focus on Sweden' written by Lars Dencik and Karl Marosi (published by the Kantor Center for the Study of Contemporary European Jewry at Tel Aviv University earlier this year). Last, Keith Kahn-Harris reviews the volume Jewish Studies in the Nordic Countries Today, 2015 .

The re-establishment of $\mathrm{NJ}$ as an open access online journal has succeeded in a way that exceeds all our expectations, and as editors we wish to thank all authors, reviewers and others, who have helped to breathe life into the journal once more and to spread information about it in international networks. We look with confidence towards next year, when we will continue by publishing two fresh issues of the journal.

\section{RUTH ILLMAN \& KARIN HEDNER ZETTERHOLM} Chefredaktörer $\bullet$ Editors-in-chief

Ruth IIIman is docent of comparative religion at Åbo Akademi University and director of the Donner Institute for Research in Religious and Cul-

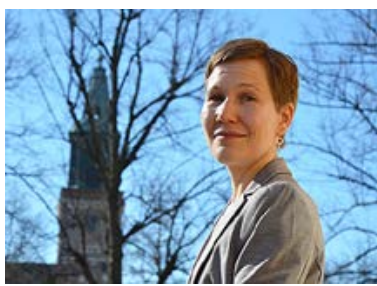
tural History in Turku, Finland. Her main research interests include interreligious dialogue, religion and art, and contemporary Judaism. Among her recent publications are the books Art and Belief: Artists Engaged in Interreligious Dialogue (Routledge, 2012) and Theology and the Arts: Engaging Faith, co-authored with W. Alan Smith (Routledge, 2013, paperback ed. 2016).

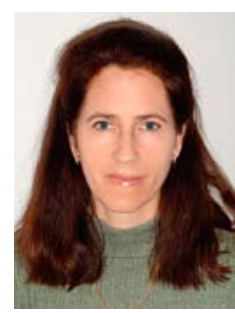

Karin Hedner Zetterholm is Associate Professor of Jewish Studies at Lund University. Her fields of interest include early Jewish biblical interpretation, interaction between rabbinic Jews and Jesus-oriented Jews in antiquity and Jewish-Christian relations. She is the author of Jewish Interpretation of the Bible: Ancient and Contemporary (Fortress Press, 2012) and Portrait of a Villain: Laban the Aramean in Rabbinic Literature (Peeters, 2002), and of numerous articles on rabbinic Judaism and relations between rabbis and Jesus-oriented Jews. She is currently involved in a multidisciplinary project on identity formation processes within early Judaism and Christianity. 